\title{
Chemical inactivation of recombinant vaccinia viruses and the effects on antigenicity and immunogenicity of recombinant simian immunodeficiency virus envelope glycoproteins
}

\author{
Ellen G.J. Hulskotte*†, Marlinda E.M. Dings*†, Stephen G. Norley $\ddagger$ and \\ Albert D.M.E. Osterhaus* $\$$
}

The efficiency of paraformaldehyde (PFA) and binary ethylenimine (BEI) in inactivating recombinant vaccinia virus $(r V V)$, present in baby hamster kidney cells expressing simian immunodeficiency virus envelope glycoproteins (SIV-Env), was measured in a series of inactivation studies. Both compounds were shown to be effective in reducing $r V V$ titres. The use of standard 3-day titration assays proved to be inadequate to measure PFA inactivation, since upon prolonged incubation, residual $r V V$ infectivity was detected in cultures negative at 3 days. Different procedures using PFA or BEI were selected to assess their influence on the antigenicity and immunogenicity of $r V V$ expressed SIV-Env. Antigenicity, as defined by the ability to react with a panel of monoclonal antibodies recognizing major antigenic sites, and immunogenicity, as defined by the ability to induce SIV envelope specific and virus neutralizing serum antibodies in rats, proved to be presened after either inactivation procedure. These data show that both protocols using PFA or BEI can be used successfully as part of the procedures to remove residual rVV infectivity. (C) 1997 Elsevier Science Ltd.

Keywords: paraformaldehyde; vaccinia virus: SIV

For the development of vaccines against human and animal lentiviruses, the use of viral subunits produced. by recombinant DNA techniques is currently being evaluated. For this purpose, expression of viral proteins by recombinant vaccinia viruses ( $r V V s$ ) is attractive for several reasons (for a review see Moss'). One of the conditions for the use of antigens produced in this way is the adequate removal of rVV infectivity from the final vaccine formulation. To this end, several chemical and physical procedures are available which should, however, not affect the antigenicity and immunogenicity of the proteins expressed.

Inactivation by formaldehyde is one of the procedures most frequently used to inactivate viruses in viral vaccines, although infections resulting from residual virus infectivity in formaldehyde inactivated vaccine formulation have been reported ${ }^{2}$. Formalde-

\footnotetext{
*Institute of Virology, Erasmus University Rotterdam, P.O. Box 1738, 3000 DR Rotterdam, The Netherlands. +Laboratory of Vaccine Development and Immune Mechanisms, National Institute of Public Health and Environmental Protection, Bilthoven, The Netherlands. $\Varangle$ Paul-Ehrlich Institute, Langen, Germany. §To whom correspondence should be addressed. (Received 19 May 1997; accepted 23 May 1997)
}

hyde reacts with amino, imino, amido, sulphydryl and hydroxy groups and with peptide linkages within proteins. One of its principal advantages is that, as a result of cross-linking, the gross three-dimensional architecture of proteins is conserved. In fact, the oligomeric form of the envelope glycoprotein of human immunodeficiency virus (HIV) has been shown to be stabilized by formaldehyde treatment ${ }^{3}$. However, one drawback in the use of formaldehyde is the possible alteration or destruction of epitopes, which may result in an immunogen eliciting ineffective or even deleterious immune responses ${ }^{4.5}$. The antigenic structure of several membrane proteins has been shown to be best preserved by paraformaldehyde (PFA), the polymeric form of formaldehyde ${ }^{6}$. In addition, antigen presenting cell function has been shown to be maintained after PFA fixation ${ }^{7-9}$.

Alternatively, one can hypothesize that compounds which inactivate viral infectivity without interaction with proteins would better preserve the antigenic structure of a protein. One of the most widely used compounds in this respect is binary ethylenimine (BEI), an aziridine compound reacting with nucleic acids, which has been shown to efficiently inactivate several RNA and DNA viruses (for a review see Bahnemann"). 
In the present paper we evaluate the effects of both PFA and BEI treatment on the infectivity of rVVs in relation to their influence on the antigenicity and immunogenicity of the recombinant SIV-Env which they express.

\section{MATERIALS AND METHODS}

\section{Recombinant vaccinia viruses}

The rVVs used in this study were: vSC65, a control rVV made by homologous recombination of the pSC65 vector with vaccinia virus (WR strain) ${ }^{11}$; v8672-m and v8789-m, rVVs containing the cleavage site mutated 8672-20 and 8789-11 SIV envelope gene, respectively ${ }^{12}$. These SIV envelope genes were derived from SIVmac32H after different in vivo passages ${ }^{12}$.

\section{Inactivation experiments}

Vaccinia virus infection. RVV was incubated in $0.25 \mathrm{mg} \mathrm{ml}^{-1}$ trypsin for $20 \mathrm{~min}$ at $37^{\circ} \mathrm{C}$ and vortexed regularly. Baby hamster kidney (BHK) cells were infected with the vaccinia virus preparation at a multiplicity of infection of 1 . After $24 \mathrm{~h}$ of incubation in complete medium (CM: Dulbecco's Modified Eagles Medium, penicillin $\left(100 \mathrm{IU} \mathrm{ml}^{-1}\right)$, streptomycin $\left(100 \mathrm{G} \mathrm{ml}^{-1}\right)$, L-glutamine $(2 \mathrm{mM}), \beta$-mercaptoethanol $\left.\left(2 \times 10^{-5} \mathrm{M}\right)\right)$ supplemented with $5 \% \mathrm{FCS}$, cells were collected by centrifugation.

PFA inactivation procedure. A PFA (Merck, Darmstadt, Germany) stock in PBS (pH 7.3) was freshly prepared before each experiment. To solubilize the PFA, $0.1 \% 4 \mathrm{~N} \mathrm{NaOH}$ was added, followed by neutralization with an equal molar amount of $4 \mathrm{M}$ $\mathrm{HCl}$. Twenty-four hours after vaccinia virus infection, $\mathrm{BHK}$ cells were harvested by centrifugation and resuspended in PBS at a concentration of $10^{7} \mathrm{ml}^{-1}$. A $1 \mathrm{ml}$ sample was taken to quantify vaccinia virus in the starting material. The remaining cell preparation was mixed with an equal volume of an appropriate PFA solution giving a final concentration of either $0.3 \%$ or $1.5 \%$ or $7.5 \%(w / v)$ PFA. Samples were incubated at room temperature (RT) for various lengths of time as indicated. Thereafter, $10 \%$ (w/v) $1 \mathrm{M}$ glycine (Merck) in PBS was added to stop the inactivation. Cells were centrifuged and resuspended in $0.2 \mathrm{M}$ glycine in PBS. After $1 \mathrm{~h}$ incubation at RT, cells were collected by centrifugation, resuspended in $\mathrm{CM}$ at a concentration of $2 \times 10^{7}$ cells $\mathrm{ml}^{-1}$, and stored at $-70^{\circ} \mathrm{C}$ until used for titration.

BEI inactivation procedure. BEI was prepared freshly before each experiment according to a procedure described elsewhere ${ }^{10}$. Briefly, 2-bromoethylamine (BEA, Sigma, St. Louis, MO, USA) was dissolved in $0.175 \mathrm{~N} \mathrm{NaOH}$ to a concentration of $0.1 \mathrm{M}$ and incubated at $37^{\circ} \mathrm{C}$ for $30-60 \mathrm{~min}$ to allow cyclization. The formation of BEI was verified by measuring the $\mathrm{pH}$ which dropped from 12.5 to 8.5 . As initial studies performed with $1.5 \mathrm{mM}$ BEI in DMEM containing $1 \mathrm{mM}$ ethylene-diamine-tetra-acetic acid (EDTA, Merck), 2 mM phenyl-methyl-sulfonyl-fluoride (PMSF, Sigma), $2 \mu \mathrm{g} \mathrm{ml}^{-1}$ leupeptin (Sigma) and $2 \%$ FCS did not allow consistent vaccinia virus inactivation, further experiments were conducted in PBS (pH 7.6) containing $1 \mathrm{mM}$ EDTA, $2 \mathrm{mM}$ PMSF and $2 \mu \mathrm{g} \mathrm{ml}$ leupeptin at varying BEI concentrations and incubation periods. Twenty-four hours after vaccinia virus infection, BHK cells were harvested by centrifugation and resuspended at $10^{7} \mathrm{ml}^{-1}$ in PBS ( $\left.\mathrm{pH} 7.6\right)$. A $1 \mathrm{ml}$ sample was taken to quantify vaccinia virus in the starting material. The remaining cells were mixed with 0.1 M BEI at a final concentration of either $1.5 \mathrm{mM}$ or $7.5 \mathrm{mM}$. To control for decline in vaccinia virus infectivity in time, a control sample without BEI was run in parallel. After incubation at $37^{\circ} \mathrm{C}$ for various lengths of time as indicated, virus inactivation was stopped by the addition of $1 \mathrm{M}$ sodium-thiosulphate at $10 \%$ of the volume of the BEI solution used. Samples were stored at $-70^{\circ} \mathrm{C}$ until used for titration.

Infectivity assessment by 3-day plaque titration. Trypsin (Gibco BRL, Life Technologies, Paisley, Scotland) was added to $100 \mu \mathrm{l}$ of each sample at $0.25 \mathrm{mg} \mathrm{ml}^{-1}$ and incubated for $20 \mathrm{~min}$ at $37^{\circ} \mathrm{C}$. Ten-fold serial dilutions in $\mathrm{CM}$ were made and $100 \mu \mathrm{l}$ aliquots were added in quadruplicate to rabbit kidney cells (RK13 cells) seeded in 24-well plates (Costar, Cambridge, USA). In addition, $100 \mu$ l aliquots of each undiluted sample were added in quadruplicate to RK13 cells. Samples were incubated on a rocker for $90 \mathrm{~min}$ at RT, diluted with $1 \mathrm{ml}$ of $\mathrm{CM}$ containing $2.5 \%$ FCS and further incubated at $37^{\circ} \mathrm{C} / 5 \% \quad \mathrm{CO}_{2}$ for 3 days. To count plaques, cells were stained with $0.8 \%$ crystal violet in $50 \%$ ethanol $/ 5 \%$ formalin. Virus titre was defined as the number of plaque forming units per millilitre (pfu $\mathrm{ml}^{-1}$ ) containing $10^{7}$ vaccinia virus-infected BHK cells. The detection threshold was $2.5 \mathrm{pfu} \mathrm{ml}{ }^{1}$.

Long-term (21 day) infectivity assessment. Samples were prepared as described above. $200 \mu \mathrm{l}$ of undiluted or $500 \mu \mathrm{l}$ of ten-fold serial diluted trypsinized sample was added to RK13 cells seeded in $25 \mathrm{~cm}^{2}$ flasks and incubated on a rocker for $90 \mathrm{~min}$ at RT. Subsequently, $4 \mathrm{ml}$ of CM containing $2.5 \%$ FCS was added and the flasks were further incubated at $37^{\circ} \mathrm{C} / 5 \% \quad \mathrm{CO}_{2}$ for 3 weeks. Cultures were split 1 in 5 twice a week.

\section{Production of recombinant SIV-Env and preparation of iscoms}

The production of SIV-Env and their incorporation into iscoms was performed as described previously ${ }^{12}$. Briefly, BHK cells were infected with either rVV $\mathrm{v} 8672-\mathrm{m}$ or $\mathrm{v} 8789-\mathrm{m}^{12}$. Subsequently, cells were collected and treated with either $1.5 \%$ PFA in PBS for $30 \mathrm{~min}$ at RT or with $1.5 \mathrm{mM}$ BEI in DMEM containing $1 \mathrm{mM}$ EDTA, $2 \mathrm{mM}$ PMSF and $2 \mu \mathrm{g} \mathrm{ml}^{-1}$ leupeptin and $2 \% \mathrm{FCS}$ for $24 \mathrm{~h}$ at $37^{\circ} \mathrm{C}$. The envelope proteins were solubilized from the mombrane by incubation in 4\% Rosenbuch-Tenside (RBT, $n$-octylpolyoxy-ethylene; Bachem, Bubendorf, Switzerland), enriched by lentil-lectin chromatography and incorporated into iscoms by the dialysis method.

\section{Immunization of rats}

Two groups of four female rats (RIV:tox) were immunized intramuscularly at weeks 0 and 4 with $3 \mu \mathrm{g}$ of 8789-m SIV-Env incorporated into iscoms. The Env was solubilized from rVV-infected BHK cells treated 
with either $1.5 \%$ PFA for $30 \mathrm{~min}$ at RT or $1.5 \mathrm{mM} \mathrm{BEI}$ for $24 \mathrm{~h}$ at $37^{\circ} \mathrm{C}$. Serum samples were collected $0,2,4$, $5,6,8$, and 14 weeks after the first immunization.

\section{Binding of monoclonal antibodies (Moabs) to different SIV-Env preparations}

The reactivity of SIV-Env $8672-\mathrm{m}$ and $8789-\mathrm{m}$, derived from either non-inactivated or PFA or BEI inactivated rVV-infected BHK cells, with a panel of Moabs (kindly provided by Dr K. Kent, in part through MRC) was tested by ELISA as described ${ }^{12}$. The panel consisted of 14 murine Moabs which could be divided into six competition groups ${ }^{13,14}$ located at the surface and transmembrane part of the SIV-Env (see also Figure 3). The Moabs of competition group 1 recognize conformation dependent epitopes. 'They all crosscompete but differ in their ability to react with different strains of SIV, to compete with Moabs recognizing the V3 region of SIV, and to inhibit CD4-gp120 binding ${ }^{15-17}$. Further mapping has shown that the conformation dependent epitope recognized by KK9 involves the V3 and the V4 domain, that the epitope of KK5 involves V4 but not V3, and that KK56 recognizes a conformation dependent epitope involving the CD4 binding site ${ }^{15}$.

\section{Detection of SIV-Env specific antibodies}

Envelope specific antibodies were detected by a whole SIV ELISA as described ${ }^{12}$. Briefly, concanavalinA-coated 96-well plates were incubated with a SIV-infected C8166 cell lysate. After overnight incubation, wells were blocked and incubated with two-fold dilutions of rat serum. Bound antibody was detected by rabbit-anti-rat Ig-horseradish peroxidase (HRPO) antibodies (DAKO, Gostrup, Denmark). The substrate reaction was carried out with $3,3^{\prime}, 5,5^{\prime}$-tetramethylbenzidine. Endpoint titres were calculated using as cut-off value twice the $\mathrm{OD}_{451}$ given by parallel dilutions of the pre-immune serum. Comparison of titres between the immunization groups was conducted using a one-way analysis of variance (Anova; Minitab Inc., State College, USA). Titres were considered significantly different if $P<0.05$.

\section{Inhibition of a virus neutralizing antibody (KK56)}

To demonstrate the presence of antibodies capable of inhibiting the virus neutralizing (VN) antibody $\mathrm{KK} 56^{16}$, an inhibition ELISA was used as described ${ }^{18}$ with minor modifications. Briefly, concanavalinA-coated 96-well plates were incubated with $100 \mu$ of SIV-infected C8166 cell lysate. Two-fold dilutions of rat serum in $100 \mu \mathrm{l}$ were added for $1 \mathrm{~h}$ at RT. Subsequently, $50 \mu \mathrm{l}$ was replaced with $50 \mu \mathrm{l}$ of KK56 diluted to give an absorbance at $\mathrm{OD}_{450}$ of $70 \%$ of the maximum absorbance in an indirect SIV-ELISA. Plates were incubated with a biotin-conjugated goat-antimouse IgG antibody preparation (Amersham), and subsequently with HRPO conjugated streptavidine (Amersham). Inhibition titres were defined as the dilution of rat serum inhibiting $50 \%$ of the absorbance measured without competing antibody. The difference in titre between the two immunization groups was evaluated through a Student's $t$-test. Differences of $P<0.05$ were considered significant.

\section{SIV neutralization assay}

The SIV neutralization assay was performed with SIVmac32H as described ${ }^{\text {Is }}$. Briefly, $10 \mu \mathrm{l}$ of serial dilutions of heat-inactivated sera were incubated in four replicate wells with $10 \mu \mathrm{l}$ of SIVmac32H at 10 infectious particles per $10 \mu \mathrm{l}$. After $30 \mathrm{~min}$ incubation at $37^{\circ} \mathrm{C}, 2 \times 10^{3} \mathrm{C} 8166$ cells in $200 \mu \mathrm{l}$ were added to each well. Cells were incubated for 7 days at $37^{\circ} \mathrm{C}$, transferred to poly-L-lysine flat-bottom microtiter plates, fixed in methanol, and examined for SIV infection by a SIV specific immunoperoxidase assay. The number of negative wells was used to determine the neutralizing dose 50\% endpoint (ND50) for that serum by the method of Spearmann-Karber. The difference in titre between the two immunization groups was evaluated through a Student's $t$-test. Differences of $P<0.05$ were considered significant.

\section{RESULTS}

\section{Inactivation of vaccinia viruses in BHK cells}

(i) PFA inactivation. Three concentrations of PFA, $0.3 \%, 1.5 \%$ and $7.5 \%$, were tested for their ability to inactivate rVVs present in BHK cells. The kinetics of inactivation were determined by assessing residual infectivity in a 3-day plaque titration assay (Figure 1A). Complete inactivation of rVVs appeared to be achieved with all three concentrations of PFA, within about $0.5,8$ and $50 \mathrm{~min}$, respectively. The rate of inactivation was found to increase with the concentration of PFA (Figure /B). However, when

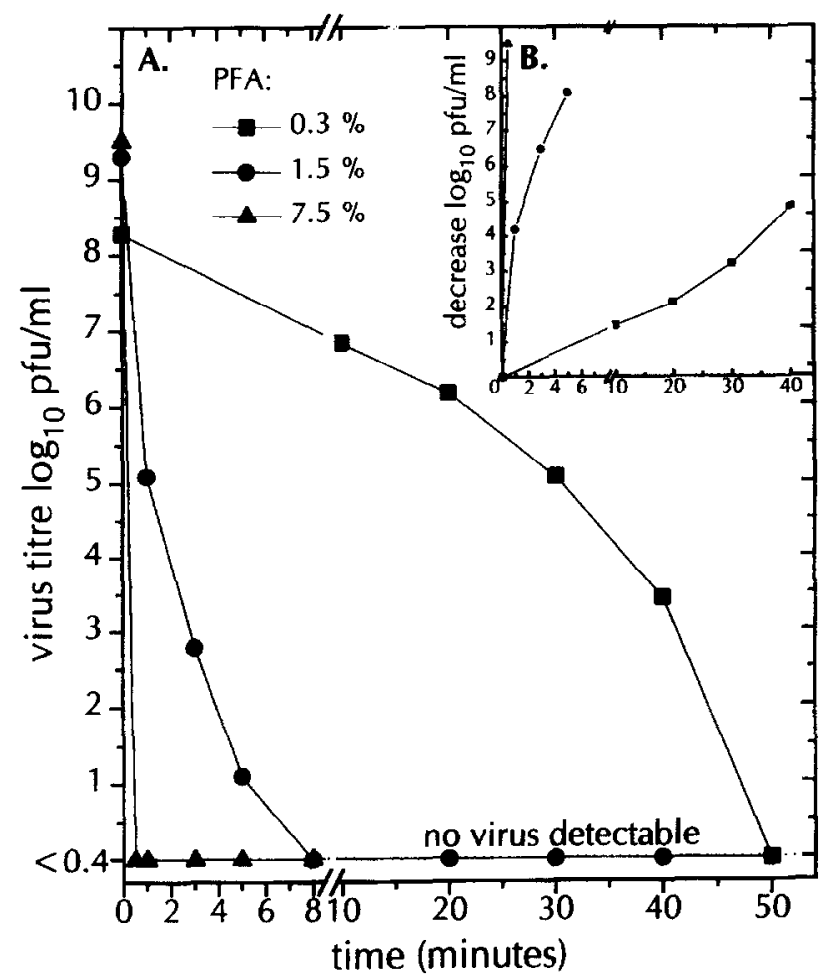

Figure 1 Inactivation of rVVs present in BHK cells with $0.3 \%$, $1.5 \%$ and $7.5 \%$ PFA at RT as measured by assessing residual infectivity in a 3-day plaque titration assay. (A) Kinetics of inactivation of vaccinia virus. (B) Extrapolation of the decrease of vaccinia virus infectivity in time. The data shown are representative for at least two independent experiments. Inactivation curves were generated using control rVV vSC65, expressing no recombinant protein, or rVVs v8672-m or v8789-m expressing SIV-Env 
cultures were maintained for prolonged periods, residual infectivity could be detected in all PFA treated samples within 3 weeks (see Table 1). In none of the concentrations tested did the effective inactivation with PFA therefore exceed $10^{6} \mathrm{pfu} \mathrm{ml}^{-1} \mathrm{rVV}$-infected BHK cells. As PFA interacts with proteins, we subsequently tested the effects of different concentrations and incubation times of PFA inactivation on the yields of SIV-Env obtained from rVV-infected cell preparations by detergent solubilization. As shown in Table 1 , the recovery of SIV-Env proved to be inversely related to PFA concentration and duration of treatment.

(ii) BEI inactivation. In pilot experiments, inactivation of vaccinia virus with $\mathrm{BEI}$ was shown to be more efficient at $37^{\circ} \mathrm{C}$ compared to $20^{\circ} \mathrm{C}$ (data not shown). Therefore, two concentrations of BEI, $1.5 \mathrm{mM}$ and $7.5 \mathrm{mM}$, were tested for their ability to inactivate vaccinia virus at $37^{\circ} \mathrm{C}$ using different incubation periods (Figure 2A). Complete inactivation of rVVs was found with both concentrations of BEI, within 8 and $24 \mathrm{~h}$, respectively. The rate of inactivation was found to increase with the concentration of BEI (Figure 2B). In contrast to inactivation with PFA, inactivation with BEI did not result in recovery of residual infectivity upon prolonged incubation (Table I).

\section{Antigenicity of rVV expressed SIV-Env after PFA and BEI treatment}

On the basis of their inactivation kinetics and for practical reasons, the following procedures using PFA and BEI were selected to evaluate their effects on antigenicity and immunogenicity, respectively: $1.5 \%$ PFA for $30 \mathrm{~min}$ at RT; $1.5 \mathrm{mM}$ BEI for $24 \mathrm{~h}$ at $37^{\circ} \mathrm{C}$. The effect of PFA and BEI inactivation on the antigenicity of rVV v8672-m and rVV v8789-m expressed SIV-Env was assessed by evaluating their reactivity with a panel of 14 SIV envelope specific Moabs recognizing major antigenic sites ${ }^{13,14}$ (Figure 3). These Moabs included the virus neutralizing Moabs KK10 and KK54 recognizing linear epitopes and KK5, KK9, and KK56 recognizing different conformation dependent epitopes ${ }^{13-17}$. With all the Moabs tested, the reactivity of PFA or BEI treated SIV-Env was essen- tially the same as that of SIV-Env recovered without prior use of an inactivation method.

\section{Immunogenicity of RVV expressed SIV-Env after PFA and BEI treatment}

To investigate the immunogenicity of SIV-Env, rats were immunized with rVV v8789-m expressed SIV-Env incorporated into iscoms after inactivation either with PFA or BEI. The overall levels and kinctics of SIV specific antibody titres were virtually identical in rats immunized with either PFA or BEI treated SIV-Env (Figure 4A). In addition, no significant difference was found in titres of serum antibodies capable of inhibiting the VN antibody KK56, as well as total VN serum antibodies (Figure $4 \mathrm{~B}$ and $\mathrm{C}$ ). Similar results were obtained using rVV v8672-m expressed SIV-Env incorporated into iscoms for immunization (data not shown).

\section{DISCUSSION}

In the present study, we have shown that both PFA and BEI inactivate vaccinia virus in a dose- and timedependent fashion. However, in samples which scored virus negative in a standard 3-day plaque titration assay, residual infectivity could be detected in PFA but not BEI treated samples when cultures were maintained for up to 3 weeks. Treatment of rVV-infected BHK cells with $1.5 \%$ PFA for $30 \mathrm{~min}$ at RT or $1.5 \mathrm{mM} \mathrm{BEI}$ for $24 \mathrm{~h}$ at $37^{\circ} \mathrm{C}$ preserved the reactivity of $\mathrm{rVV}$ expressed SIV-Env with a panel of 14 Moabs recognizing the major antigenic sites on the SIV envelope glycoprotein. The immunogenicity of SIV-Env, as defined by SIV spccific scrum antibody titres, inhibition to a VN monoclonal antibody and total VN antibody titre against SIVmac32H, proved to be comparable using either inactivation method.

Formaldehyde is widely used to inactivate viral vaccines ${ }^{19}$. However, accidents due to residual virus infectivity in formaldehyde inactivated vaccine preparations have been reported ${ }^{2}$. Residual infectivity has been attributed to non-linearity of the inactivation curves, reversion of the process of formaldehyde mediated inactivation, slow adsorbtion of formaldehyde treated virus to cells, and retarded penetration of the virus into

Table 1 Measurement of residual vaccinia virus infectivity using a 3-or 21-day titration assay and recovery of SIV-Env from differently inactivated $\mathrm{VV}$ infected $\mathrm{BHK}$ cells

\begin{tabular}{|c|c|c|c|c|}
\hline \multirow[b]{2}{*}{ Compound } & \multirow[b]{2}{*}{ Incubation period (min) } & \multicolumn{2}{|c|}{$\begin{array}{l}\text { Decrease in infectivity } \\
\left(\log \text { pfu } \mathrm{ml}^{-1}\right)\end{array}$} & \multirow[b]{2}{*}{ Yield $^{c}\left(\mu \mathrm{g}\right.$ SIV-Env $\left.\mathrm{ml}^{-1}\right)$} \\
\hline & & 3 days $^{a}$ & 21 days $^{b}$ & \\
\hline \multirow[t]{3}{*}{$7.5 \%$ PFA } & 0.5 & $>8$ & 6 & nd \\
\hline & 1.5 & $>8$ & nd & 0.7 \\
\hline & 3 & $>8$ & 6 & 0.4 \\
\hline \multirow[t]{2}{*}{$1.5 \%$ PFA } & 15 & $>8$ & 5 & 3.1 \\
\hline & 30 & $>8$ & 6 & 2.8 \\
\hline \multirow[t]{3}{*}{$0.3 \%$ PFA } & 60 & $>8$ & 3 & nd \\
\hline & 180 & $>8$ & nd & 4.2 \\
\hline & 360 & $>8$ & 6 & 2.4 \\
\hline $1.5 \mathrm{mM} \mathrm{BEl}$ & $24 \mathrm{~h}$ & $>8$ & $>8$ & nd \\
\hline
\end{tabular}

${ }^{a}$ Decrease in vaccinia virus infectivity as determined in a standard 3-day plaque titration assay

Decrease in vaccinia virus infectivity as determined by maintenance of cultures for 21 days

cYield of SIV-Env obtained from rVV v8789-m infected BHK cefl preparations by solubilization with $4 \%$ RBT nd: not done 
the cell ${ }^{2.2 n-2+}$. In the present study, using PFA for inactivation, residual vaccinia virus infectivity was found in cultures that had scored virus negative in a standard 3-day plaque titration assay, after additional culturing for up to 3 weeks. Apparently, the conditions used did not result in an inactivation of more than six logs. In contrast, the calculated inactivation which would result from a hypothetical inactivation curve based on extrapolation of the data obtained in the 3-day plaque titration assay would have been more than $10^{30}$ pfu $\mathrm{ml}$ ' (1.5\% PFA for $30 \mathrm{~min}$ at RT). It therefore seems most likely that the late recovery of infectivity is due to a delay in regaining virus infectivity rather than to an asymptotic nature of the inactivation curve. However, more detailed experiments are needed to elucidate the exact underlying mechanism, and whether for instance the relapse in infectivity could be overcome by changing the conditions used, such as even longer incubation periods, higher concentrations of PFA, or different incubation temperatures. Inactivation of vaccinia virus in this study may also have been complicated by the fact that inactivation is carried out with intact vaccinia virus-infected cells and not with cell free virus.

From these data it has become clear that inactivation based solely on PFA treatment may not be sufficient. In the procedure to make the experimental SIV-Env vaccine preparation used for immunization, additional steps to isolate and purify the protein may have contributed to inactivating or removing vaccinia virus. These steps include detergent extraction, which

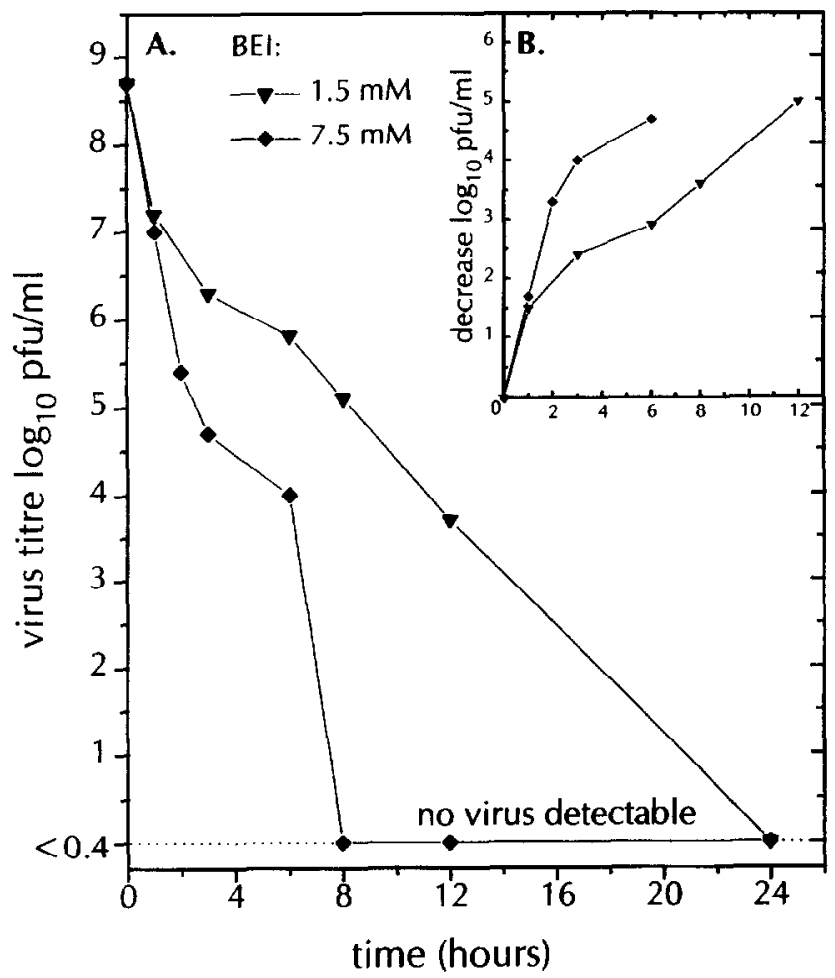

Figure 2 Inactivation of $\mathrm{PV}$ s present in BHK cells with $1.5 \mathrm{mM}$ and $7.5 \mathrm{mM} \mathrm{BEl}$ at $37^{\circ} \mathrm{C}$ as measured by assessing residual infectivity in a 3-day plaque titration assay. (A) Kinetics of inactivation of vaccinia virus. (B) Extrapolation of the decrease of vaccinia virus infectivity in time. The data shown are representative for at least two independent experiments. Inactivation curves were generated using control rVV vSC65, expressing no recombinant protein, or rVVs v8672-m or v8789-m expressing SIV-Env reduces infectivity with at least six logs (data not shown), lentil-lectin affinity chromatography and iscom preparation including dialysis and sucrose gradient centrifugation, which in general give additional reductions in virus titre of about threc to four logs each ${ }^{25}$. We could never demonstrate residual infectivity in iscom preparations produced in this way: neither in vitro (data not shown) nor in vivo upon immunization of rats (present study and Hulskotte et $\left.a^{1{ }^{2}}{ }^{2}\right)$ or monkeys ${ }^{2(1}$ with recombinant SIV-Env derived from $\mathrm{rVV}$-infected BHK cells originally containing about 0.3 to $1 \times 10^{4} \mathrm{pfu}$ per immunization dose, respectively.

In several studies BEI has been shown to efficiently inactivate RNA and DNA viruses ${ }^{10}$. Inactivation was found to be linear in time with inactivation rates ranging from 0.5 to $4.1 \log \mathrm{h}^{\prime}$ using $1 \mathrm{mM}$ BEI at $37^{\circ} \mathrm{C}^{111}$. In our study, the calculated inactivation rate of vaccinia virus with $1.5 \mathrm{mM} \mathrm{BEI}$ at $37^{\circ} \mathrm{C}$ was on average

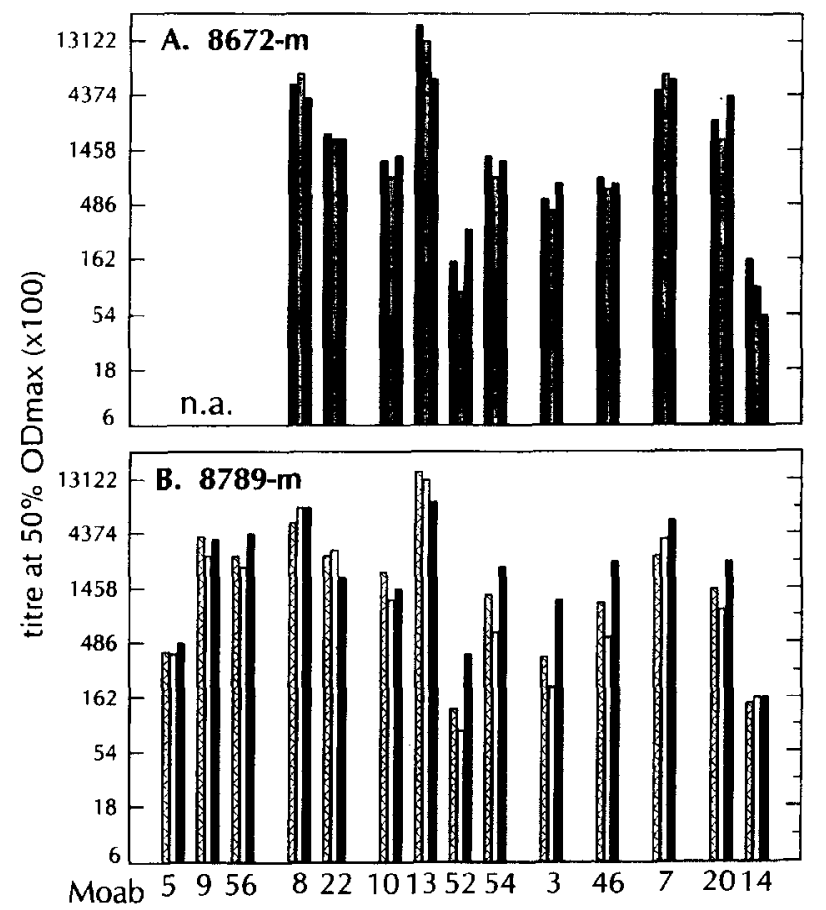

\begin{tabular}{|c|c|c|c|c|c|c|c|}
\hline comp. group & 1 & 2 & 3 & 4 & - & 5 & 6 \\
\hline $\begin{array}{c}\text { specificity } \\
\text { aa }\end{array}$ & conf. & SU & SU (V2) & SU & SU(V3) & TM & $T M$ \\
& & $8-30$ & $171-190$ & $21-40$ & $321-340$ & $493-735$ & $594-616$ \\
\hline
\end{tabular}

Figure 3 Binding of 14 Moabs to rVV v8672-m (A) and rVV v8789-m (B) expressed SIV envelope glycoproteins recovered either without prior use of an inactivation procedure for vaccinia virus or after inactivation with $1.5 \%$ PFA for $30 \mathrm{~min}$ at RT or with $1.5 \mathrm{mM} \mathrm{BEI}$ for $24 \mathrm{~h}$ at $37^{\circ} \mathrm{C}$. Competition groups are defined by Kent et al. ${ }^{13.14 .16}$. The Moabs of competition group 1 recognize conformation dependent epitopes. They all cross-compete but differ in their ability to react with different strains of SIV, to compete with Moabs recognizing the V3 region of SIV and to inhibit CD4-gp120 binding ${ }^{15-17}$. SU, surface glycoprotein; TM, transmembrane glycoprotein; Aa, amino acid numbers BK28 SIV envelope protein; conf., conformation dependent epitope; na, not applicable, $8672-m$ envelope glycoprotein is hardly recognized by Moabs of competition group $1^{12}$. Bars represent the dilution of monoclonal antibody giving 50\% of the maximum OD450 using that monoclonal antibody. $\square$ : 8672-m; 9 : 8672-m PFA; 8672-m BEl; > : 8789-m; $\square$ : 8789-m PFA; $\mathbf{n}$ : 8789-m BEl. Binding of Moabs to untreated $8672-\mathrm{rl}$ and $8789-\mathrm{m}$ envelope glycoproteins has been published before in Hulskotte et al. ${ }^{12}$ 
weeks post primary immunization

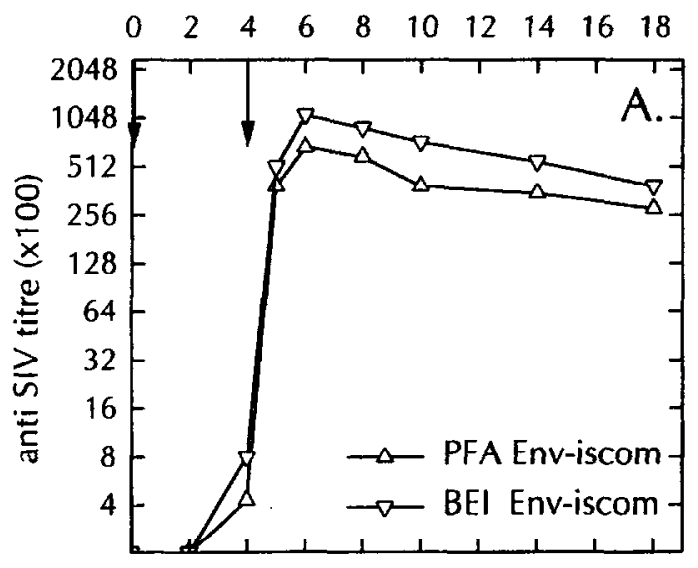

KK56 inhibition titre

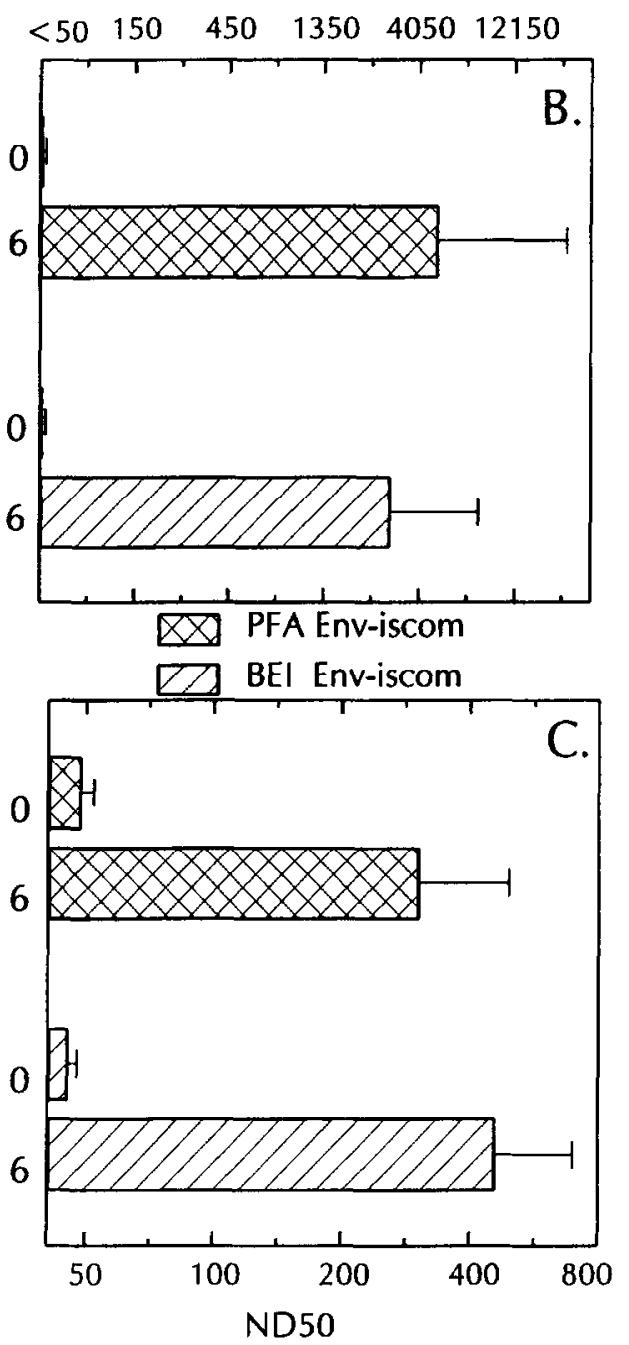

Figure 4 Induction of SIV-Env specific antibodies in rats immunized with rVV v8789-m expressed SIV-Env incorporated into iscoms after inactivation either with PFA or BEI. Data on SIV-Env specific antibody induction after PFA treatment have been published before in Hulskotte et al. ${ }^{12}$. (A) Mean SIV antibody titre from four rats immunized with the same SIV-Env preparation. Weeks of immunization are indicated by arrows. (B) Inhibition of binding of the virus neutralizing monoclonal antibody KK56 by monkey sera. (C) SIV virus neutralizing antibody response before immunization (Week 0) and at peak level of antibody response (Week 6 post-primary immunization). Mean titres from four rats are shown with the standard error of the means presented as a horizontal line about $0.4 \log \mathrm{h}$ 1. A more detailed analysis of the inactivation curves will be needed to precisely determine the inactivation rate at all stages.

There are several indications that the SIV envelope protein did not dramatically change its conformation by either the PFA or the BEI treatment. First, the recognition of the envelope protein by a group of $\mathrm{VN}$ antibodies specific for conformational epitopes was preserved. Second, VN antibodies were induced by immunization with PFA or BEI treated SIV-Env. As large parts of $\mathrm{VN}$ antibodies present in sera from SIV-infected monkeys ${ }^{27}$ and HIV-infected humans ${ }^{2 x, 29}$ are conformation dependent, this finding may indicate a rather native conformation of the SIV-Env studied. Our results with PFA treated SIV-Env are also in agreement with the findings of Sattentau et al..$^{30}$ showing the conservation of four neutralizing epitopes on HIV-1 gp120 after formaldehyde treatment.

Overall, the results generated in the present studies are encouraging for the proposed inclusion of recombinant proteins expressed by rV in experimental viral vaccines, since they show that antigenicity and immunogenicity of the highly glycosylated SIV-Env glycoprotein are preserved. Treatment of rVV infected cells with $1.5 \mathrm{mM} \mathrm{BEI}$ at $37^{\circ} \mathrm{C}$ resulted in complete inactivation. PFA treatment was shown to give a delayed appearance of residual vaccinia virus infectivity after prolonged culture, and therefore additional procedures are needed if this compound is to be used in the preparation of vaccincs for human use.

\section{ACKNOWLEDGEMENTS}

We thank K. Kent and the MRC AIDS directed programme for the gift of the SIV-Env specific Moabs, P. de Vries for helpful suggestions, L. van de Berg and J. van Kooten for biotechnical assistance, A.M. Geretti for critical reading of the manuscript and C. Kruyssen for assistance in preparing the manuscript. This investigation was supported by the Dutch Council for Health Research (RGO) and the Praeventiefonds (Grants No. 90.052 and $28-2128$, respectively).

\section{REFERENCES}

1 Moss, B. Poxviruses: The viruses and their replication. In Virology (Eds Fields, B.N., Knipe, D.M. and Howley, P.M.). Lippincott-Raven Publishers, Philadelphia, 1996, pp. 2637-2673.

2 Brown, F. Review of accidents caused by incomplete inactivation of viruses. In: Virological Safety Aspects of Plasma Derivatives (Ed. Brown, F.). Dev. Biol. Standard, 1993, Vol. 81, pp. 103-107

3 Moore, J.P. Jameson, B., Weiss, R.A and Sattentau, Q.J. The HIV-cell fusion reaction. In: Viral Fusion Mechanisms (Ed. Bentz, J.). CRC Press, Boca Raton, 1992, pp. 233-289.

4 Ferguson, M., Wood, D.J. and Minor, P.D. Antigenic structure of poliovirus in inactivated vaccines. J. Gen. Virol. 1993, 74, 685-690.

5 King, D.J. Evaluation of different methods of inactivation of Newcastle disease virus and avian influenza virus in egg fluids and serum. Avian Dis. 1991, 35, 505-514.

6 Babcock, G.F. and Dawes, S.M. Immunophenotyping using fixed cells. Methods Cell Biol. 1994, 41, 81-93.

7 Van Baalen, C.A., Klein, M.R. and Geretti, A.M. et al. Selective in vitro expansion of HLA class I restricted HIV-1 gag-specific $\mathrm{CDB}^{+} \mathrm{T}$ cells: cytotoxic T-lymphocyte epitopes and precursor frequencies. AlDS 1993, 7, 781-786.

$8 \mathrm{Hu}, \mathrm{S}$. and Caldwell, H.D. Kinetics of chlamydial antigen processing and presentation to $T$ cells by paraformaldehyde 
fixed murine bone marrow derived macrophages. Infect. Immun. 1995, 63, 946-953.

9 Geretti, A.M., Hulskotte, E.G.J., Dings, M.E.M. et al. Simian immunodeficiency virus (SIV) specific $\mathrm{CD}^{+}$cytotoxic $\mathrm{T}$ lymphocyte responses in cynomolgus macaques infected with SIVmac32H(J5): quantitative analysis by in vitro stimulation. Vaccine (in press)

10 Bahnemann, H.G. Inactivation of viral antigens for vaccine preparation with particular reference to the application of binary ethylenimine. Vaccine 1990, 8, 299-303.

11 Rimmelzwaan, G.F., Siebelink, K.H.J., Huisman, R.C., Moss, B. and Osterhaus, A.D.M.E. Removal of the cleavage site of recombinant FIV envelope protein facilitates incorporation of the surface glycoprotein in immune stimulating complexes. $J$. Gen. Virol. 1994, 75, 2097-2102.

12 Hulskotte, E.G.J., Rimmelzwaan, G.F. and Boes, J. et. al. Antigenicity and immunogenicity of recombinant envelope glycoproteins of SIVmac32H with different in vivo passage histories. Vaccine 1995, 13, 1187-1197.

13 Kent, K.A., Gritz, L. and Stallard, G. et al. Production and characterization of monoclonal antibodies to simian immunodeficiency virus envelope glycoproteins. AIDS 1991, 5, 829-836.

14 Kent, K.A., Rud, E. and Corcoran, T. et al. Identification of two neutralizing and eight non-neutralizing epitopes on simian immunodeficiency virus envelope using monoclonal antibodies. AlDS Res. Human Retrovir. 1992, 8, 1147-1151.

15 Doyle, C.B., Bhattacharyya, U., Kent, K.A., Stott, J.E. and Jones, I.M. Regions required for CD4 binding in the external glycoprotein gp120 of simian immunodeficiency virus. J. Virol. 1995, 69, 1257-1260.

16 Kent, K.A. Neutralising epitopes of simian immunodeficiency virus envelope glycoprotein. J. Med. Primatol. 1995, 24, 145-149.

17 Javaherian, K., Zuchowsiki, L. and Clark, F.T. Alanine substitution of two arginines in amino terminus of V3 of SIV disrupts CD4 binding whereas a similar replacement of two amino acids, lysine and arginine, in the carboxyl half of $V_{3}$ prevents binding of a neutralizing monoclonal antibody. AIDS Res. Human Retrovir. 1995, 11, 1101-1105.

18 De Vries, P., Heeney, J.L. and Boes, J. et al. Protection of rhesus macaques from SIV infection by immunization with different experimental SIV vaccines. Vaccine 1994, 12, $1443-1452$.
19 Murphy, B.R. and Chanock, R.M. Immunization against viruses. In: Virology, 2nd Edn, Vol. 1 (Eds Fields, B.N., Knipe, D.M., Chanock, R.M. et al.) Raven Press, New York, 1990, pp. 469-502.

20 Wesslén, T., Lycke, E. and Olin, G. Inactivation of poliomyelitis virus by formaldehyde. Arch. Ges. Virusf. 1957, 7, 394-401.

21 Gard, S. and Lycke, E. Inactivation of poliovirus by formaldehyde. Analysis of inactivation curves. Arch. Ges. Virusf. 1957, $7,471-493$

22 Graves, J.H. Formaldehyde inactivation of foot-and-mouth disease virus as applied to vaccine preparation. Am. J. Vet. Res. 1963, 24, 1131-1135.

23 Schultz, P. Rightsel, W.A. Timm, E.A. Taylor, A.R. and McLena, W. Jr. Partially inactivated poliomyelitis virus: initiation of infection in tissue cultures. J. Immunol. 1957, 79, 497-507.

24 Böttiger, M., Lycke, E., Melén, B. and Wrange, G. Inactivation of poliomyelitis virus by formaldehyde. Incubation time in tissue culture of formalin treated virus. Arch. Ges. Virusf. 1958, $8,259-266$

25 Darling, A.J. Considerations in performing virus spiking experiments and process validation studies. In: Virological Safety Aspects of Plasma Derivatives, Vol. 81 (Ed. Brown, F.) Dev. Biol. Standard, 1993, pp. 221-229.

26 Hulskotte, E.G.J., Geretti, A.M. and Siebelink, K.H.J. et al. Vaccine-induced virus neutralizing antibodies and cytotoxic $T$ cells do not protect macaques from experimental infection with simian immunodeficiency virus SIVmac $32 \mathrm{H}(\mathrm{J} 5)$. J. Virol $1995,69,6289-6296$.

27 Javaherian, K., Langlois, A.J. and Schmidt, S. et al. The principal neutralization determinant of simian immunodeficiency virus differs from that of human immunodeficiency virus type 1. Proc. Natl. Acad. Sci. USA 1992, 89, 1418-1422.

28 Thali, M., Furman, N. and Ho, D.D. et al. Discontinuous, conserved neutralization epitopes overlapping the CD4-binding region of human immunodeficiency virus type 1 gp120 envelope glycoprotein. J. Virol. 1992, 66, 5635-5641.

29 Profy, A.T., Salinas, P.A., Eckler, L.I., Dunlop, N.M., Nara, P.L and Putney, S.D. Epitopes recognized by the neutralizing antibodies of an HIV-1-infected individual. J. Immunol. 1990 144, $4641-4647$.

30 Sattentau, Q.J. Conservation of HIV-1 gp120 neutralizing epitopes after formalin inactivation. AIDS 1995, 9, 1383-1385. 